\title{
Molecular Genetic Characterization of Fusants from Protoplast Fusion of $S$. Cerevisiae and P. Stipitis ATCC 58785
}

\author{
Fawzia Jassim Shalsh ${ }^{1}$, Noor Azlina Ibrahim ${ }^{2 *}$, Mohammed Arifullah ${ }^{2}$ and Anis Shobirin Binti Meor Hussin ${ }^{3}$ \\ ${ }^{1}$ Industrial Microbiology Department, Directorate of Agricultural Research / Ministry of Science and Technology, Iraq \\ ${ }^{2}$ Faculty of Agro Based Industry, Malaysia \\ ${ }^{3}$ Faculty of Food Science and Technology, Malaysia
}

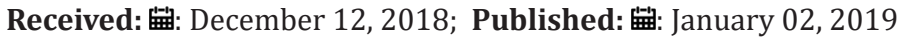

*Corresponding author: Noor Azlina Ibrahim, Faculty of Agro Based Industry, 16100, Malaysia

\begin{abstract}
Protoplast fusion is a common approach used to improve fermentation of industrial yeast strains. Molecular study using DNA content, RAPD, DNA sequences and protein profile were applied to differentiate between S. cerevisiae and P. stipitis ATCC 58785 and their fusants from protoplast fusion for improvement of biofuel production from biomass. Fusants were showed higher DNA content than that in the parental strain and DNA concentration obtained for recently generated fusant was generally lower compared to the values expected by the theoretical addition of DNA concentration from the respective parental strains. Fusants were showed new combination of DNA fragment patterns. The DNA sequencing, which includes two non-coding regions designated as the internal transcribed spacers (ITS1 and ITS2) and the 5.8S gene were performed for further confirmation of the fusant nature of fusants. According to genetic similarity and intra-species differentiation, two parent strains and fusants were grouped into two different clusters. S. cerevisiae which correspond to $88 \%$ sequence similarity whereas approximately $97 \%$ similarity was observed with P. stipitis ATCC 58785
\end{abstract}

The sequence of the ITS1, ITS2 and the 5.8S gene of each fusants was submitted to Genbank with the NCBI ACESSION NO. In general, the obtained new combination of DNA fragment patterns and the presence of new DNA fragment or the absence of existing parental DNA fragments in the fusant strains compared to their parents could be considered as indicator of nuclear fusion of the two parental nuclei in the fused protoplasts, also differences in polypeptide profile on SDS-PAGE analysis were investigated. The polypeptide profile was seen with reference to a protein ladder (GangNam-STAIN ${ }^{\mathrm{TM}}$ Prestained). SDS-PAGE protein analysis of the selected fusants and their parental strains confirmed that all fusant strains acquired and expressed many specific protein bands from the parental strains.

Keywords: S cerevisiae; P stipites; Protoplast fusion; Biofuel

\section{Introduction}

Protoplast fusion is a conventional technique even though it has been shown to be successful for strain enhancement and it is seen as significant in constructing yeast strains as it mitigates the challenges of genetic modification enforced by traditional mating systems and supports the movement of sizeable segments of genomic DNA. Protoplast fusion is a common approach used to improve fermentation of industrial yeast strains [1-3]. The ease of the technical application in addition to the materials needed for this approach makes protoplast fusion the most extensively employed technique of transformation in fungi. Hence, enzymatic approaches for proto plasting have been preferred in most laboratories [4].

\section{Methodology}

\section{Yeast Strains}

This study used two yeast strains $S$. cerevisiae and P. stipitis ATCC 58785. P. stipitis ATCC 58785 was bought from the American Type Culture Collection (ATCC). The fusant obtained from yeast by protoplast fusion.

\section{DNA Extraction}

a) The genomic DNA of S. Cerevisiae, P. Stipitis ATCC 58785 and the best tolerance fusants were extracted using AMRESCO's Yeast Genomic DNA Purification Kit. 
b) Agarose gel electrophoresis of DNA

c) All samples of genomic DNA were analyzed by agarose gel electrophoresis according to [5].

d) Random amplified polymorphic DNA (RAPD)

PCR reaction was performed with one set of primer with following 5'- 3' sequences OP-M05 (GGGAAGCGTG) and OP-V09 (TGTACCCGTC) [6]. The $10 \mu \mathrm{M}$ of each primer and $25 \mathrm{ng} / \mu \mathrm{L}$ of genomic DNA were mixed with $25 \mu \mathrm{L}$ of Maxime PCR PreMix as in Table 1. The components of the Maxime PCR PreMix kit (i-Taq) contain of i-Taq DNA polymerase ( $5 \mathrm{U} / \mu \mathrm{L})$, dNTPs $(2.5 \mathrm{mM}), 10 \mathrm{X}$ Reaction buffer and $1 \mathrm{X}$ loading buffer. The PCR was carried out in a thermal cycler programmed as in Table 2 using a thermal cycler (Gene Amp, PCR system 9700, Applied Biosystem). The PCR products were detected using $1.5 \%$ agarose gel.

Table 1: Mixture of the amplified polymorphic reaction.

\begin{tabular}{|c|c|}
\hline Components & Amount $(\boldsymbol{\mu L})$ \\
\hline Taq PCR PreMix & 5 \\
\hline Primer $(10 \mu \mathrm{M})$ & 5 \\
\hline DNA & 1.5 \\
\hline $\mathrm{ddH}_{2} \mathrm{O}$ & 13.5 \\
\hline Final volume & 25 \\
\hline
\end{tabular}

Table 2: The optimum condition of amplification of RAPD.

\begin{tabular}{|c|c|c|c|c|}
\hline No. & Phase & $\begin{array}{c}\text { Temperature } \\
\left({ }^{\mathbf{o}} \mathbf{C}\right)\end{array}$ & Time (min) & $\begin{array}{c}\text { No. of } \\
\text { cycles }\end{array}$ \\
\hline 1 & $\begin{array}{c}\text { Initial } \\
\text { denaturation }\end{array}$ & 95 & 3 & 1 \\
\hline 2 & $\begin{array}{c}\text { Denaturation } \\
-2\end{array}$ & 95 & 1 & 40 \\
\cline { 1 - 2 } 3 & Annealing & 35 & 1 & \multirow{2}{*}{1} \\
\hline 4 & Extension-1 & 72 & 1 & 1 \\
\hline 5 & Extension -2 & 72 & 10 & 1 \\
\hline
\end{tabular}

Table 3: The optimum condition of amplification of ITS sequence region.

\begin{tabular}{|c|c|c|c|c|}
\hline No. & Phase & $\begin{array}{c}\text { Temperature } \\
\left({ }^{\circ} \mathbf{C}\right)\end{array}$ & Time (Sec) & $\begin{array}{c}\text { No. of } \\
\text { cycles }\end{array}$ \\
\hline 1 & $\begin{array}{c}\text { Initial } \\
\text { denaturation }\end{array}$ & 94 & 180 & 1 \\
\hline 2 & $\begin{array}{c}\text { Denaturation } \\
-2\end{array}$ & 94 & 45 & \multirow{2}{*}{35} \\
\cline { 1 - 3 } 3 & Annealing & 52 & 60 & \\
\hline 4 & Extension-1 & 72 & 60 & 1 \\
\hline 5 & Extension -2 & 72 & 42 & 1 \\
\hline
\end{tabular}

Amplification of ITS Sequence Region: Detection of ITS sequence region for fusants strains was conducted using primers for amplification [7,8]. Fragment $600 \mathrm{bp}$ of ITS region was amplified using a forward primer ITS1 (5'- TCCGTAGGTGAACCTGCGG - $3^{\prime}$ ) and a reverse primer ITS4 (5'- TCCTCCGCTTATTGATATGC-3') [9]. The PCR amplification was performed in a total volume of $25 \mu \mathrm{l}$ containing 1.5 $\mu \mathrm{L}$ DNA ( $25 \mathrm{ng} / \mu \mathrm{L}$ ), $5 \mu \mathrm{L}$ Taq PCR PreMix, $1 \mu \mathrm{L}$ of each primer then distilled water was added into tube to a total volume of
$25 \mu \mathrm{L}$. The thermal cycling conditions was carried out in a thermal cycler programmed as in Table 3 using a thermal Cycler (Gene Amp, PCR system 9700, Applied Biosystem). The PCR products were detected using $1.5 \%$ agarose gel.

\section{Sequence Analysis}

Sequencing of gene was performed by National Instrumentation Center for Environmental Management (NICEM), Korea using DNA sequencer 3730XL (Applied Biosystem, Macro Gen Company, USA). Homology search was conducted using Basic Local Alignment Search Tool (BLAST) program which is available at the National Centre Biotechnology Information (NCBI) online at http:// www. ncbi.nlm.nih.gov and BioEdit program. Phylogenetic tree was constructed using neighbor-joining method implemented by Molecular Evolutionary Genetics Analysis (MEGA 6.0 version) software. Multiple sequence alignment was done using CLUSTALW (Multiple Sequence Alignment) that was obtained from http:// www.genome.jp/tools/clustalw/. The sequences of the fusants were submitted to Genbank.

\section{Polypeptide Profiles for Parent and Fusants Determination of Protein Concentration}

Yeast strains used were grown on sabouraud dextrose agar and subjected to incubation for 3 days at the $30 \stackrel{\circ}{ }{ }^{\circ}$. Subsequently, loop full of the yeast cells were transferred into $10 \mathrm{~mL}$ of sabouraud dextrose broth and incubated for $24 \mathrm{~h}$ at $30^{\circ} \mathrm{C}$. The yeast culture at concentration $2 \times 107 \mathrm{cell} / \mathrm{mL}$ was subsequently subjected to treatment with sonication using ultrasonic processor operating at the ultrasound frequency of $20 \mathrm{kHz}$ with fixed time of $5 \mathrm{~min}$, the disruption studies were carried out using horn tip sonicator $[10,11]$. A series of bovine serum albumin (BSA) concentrations $(0.2$ to $0.8 \mathrm{mg} / \mathrm{mL}$ ) from the stock $1 \mathrm{mg} / \mathrm{mL}$ (Table 4 ) were prepared. The absorbance of these solutions was determined at $595 \mathrm{~nm}$ and a standard curve was constructed between the BSA concentrations and the absorbance of BSA at $595 \mathrm{~nm}$ [12] All protein concentration used in SDS page were $300 \mu \mathrm{g} / \mathrm{mL}$. Before loading protein sample into sample well, protein sample was prepared by mixing protein and $0.002 \%$ bromophenol blue (BPB) with ration $6: 1$ [13]. $30 \mu \mathrm{L}$ of the samples were carefully loaded onto the wells of gel using a micropipette. The polypeptide profiles of the parent protein and fusant protein bands were seen with reference to the protein marker ranging from 10 to $245 \mathrm{kDa}$ (GangNam-STAIN ${ }^{\mathrm{TM}}$ Prestained) (Table 5).

Table 4: Series of bovine serum albumin (BSA) concentration from the stock solution.

\begin{tabular}{|c|c|c|c|}
\hline $\begin{array}{c}\text { Concentration } \\
\text { of BSA (mg/ } \\
\mathbf{m L})\end{array}$ & $\begin{array}{c}\text { Volume of } \\
\text { BSA( } \boldsymbol{\mu L})\end{array}$ & $\begin{array}{c}\text { Volume of } \\
\mathbf{d H}_{\mathbf{2}} \mathbf{0}(\boldsymbol{\mu L})\end{array}$ & $\begin{array}{c}\text { Volume of } \\
\text { Bradford } \\
\text { regent (mL) }\end{array}$ \\
\hline 0 & 0 & 50 & 2.5 \\
\hline 0.2 & 10 & 40 & 2.5 \\
\hline 0.4 & 20 & 30 & 2.5 \\
\hline 0.6 & 30 & 20 & 2.5 \\
\hline 0.8 & 40 & 10 & 2.5 \\
\hline
\end{tabular}


Table 5: Components of SDS Polyacrylamide gel.

\begin{tabular}{|c|c|c|}
\hline Components & $\begin{array}{c}\text { Stacking gel }[\mathbf{6 \%} \\
\mathbf{( w / v ) ] ~} \mathbf{~ L}\end{array}$ & $\begin{array}{c}\text { Resolving gel } \\
{[\mathbf{1 0} \% \mathbf{( w / v ) ] ~} \mathbf{~ L}}\end{array}$ \\
\hline Acrylamide- bis acrylamide & 2.5 & 10 \\
\hline Stacking gel buffer & 5 & - \\
\hline Resolving gel buffer & - & 3.7 \\
\hline $\begin{array}{c}1.5 \%(w / v) \text { ammonium per } \\
\text { sulphate }\end{array}$ & 1 & 1.5 \\
\hline ddH $_{2} \mathrm{O}$ & 11.3 & 14.45 \\
\hline TEMED & 0.015 & 0.015 \\
\hline $10 \%(\mathrm{w} / \mathrm{v})$ SDS & 0.2 & 0.3 \\
\hline
\end{tabular}

\section{Results and Discussion}

\section{DNA Content for Parent and Fusants}

For genomic DNA extraction of $S$. cerevisiae, P. stipitis ATCC 58785 and the best ethanol tolerant fusants F4, F12, F18, F22, F24, the cells used were standardized based on OD Abs at $600 \mathrm{~nm} \mathrm{1.0.}$ All extracted genomic DNA were confirmed on gel electrophoresis (Figure 1). The DNA concentrations of $S$. cerevisiae, P. stipitis ATCC 58785 and fusants strains were estimated as presented in Table 6. The DNA concentration of $S$. cerevisiae was $389.54 \pm 14.76 \mathrm{ng} / \mu \mathrm{L}, P$. stipitis was $417.18 \pm 19.21 \mathrm{ng} / \mu \mathrm{L}$, whereas that of F24 was 563.38 $\pm 19.06 \mathrm{ng} / \mu \mathrm{L}$. These results of enlarged DNA content of the fusants compared to the parent are a verification of fusant formation and hence, there had been the occurrence of multiple fusions. Also, fusants F12, F18 and F22 showed enlarged DNA concentration compared to the parent, DNA concentration were $519.21 \pm 13.03$ $\mathrm{ng} / \mu \mathrm{L}, 532.54 \pm 12.65 \mathrm{ng} / \mu \mathrm{L}$ and $512.23 \pm 12.32 \mathrm{ng} / \mu \mathrm{L}$ respectively. The inclusion of the whole chromosomes of parent strains did not happen through protoplast fusion and DNA concentration obtained for recently generated fusant was generally lower compared to the values expected by the theoretical addition of DNA concentration from the respective parental strains.

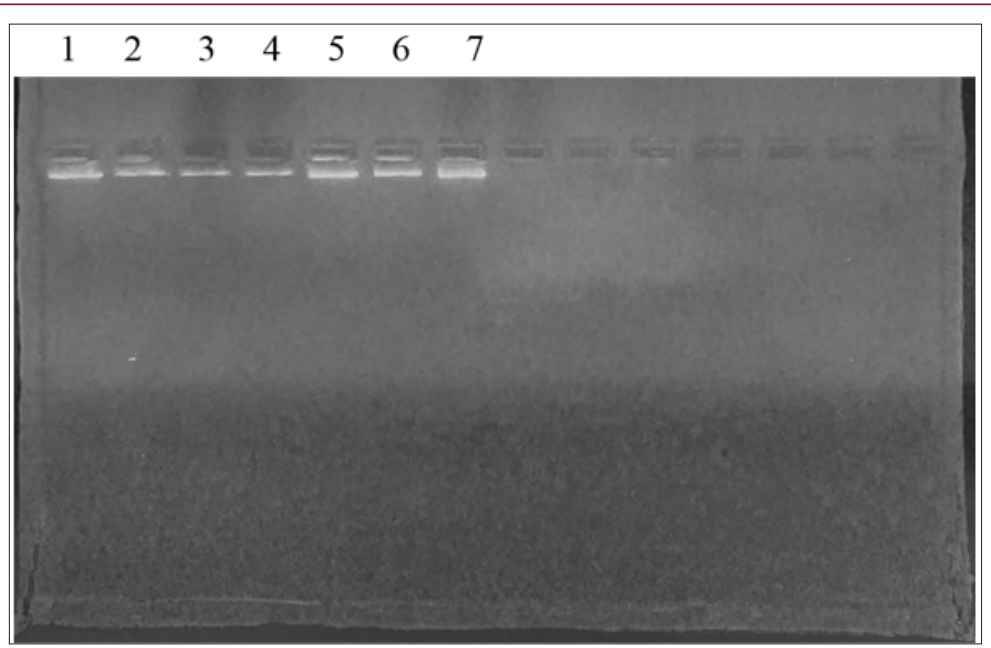

Figure 1: Gel electrophoresis of genomic DNA extraction from S. cerevisiae, P. stipitis ATCC 58785, and fusants strain. Lane 1; S. cerevisiae, Lane 2: F4, Lane 3: F12, Lane 4: F18, Lane 5: F22 Lane 6: F24 and Lane 7: P. stipitis ATCC 58785 electrophoresis on $1.5 \%$ agarose with 1 X TBE buffer at 70 voltage for $1.5 \mathrm{~h}$ and visualized under U.V light.

Table 6: Total DNA content of the S. cerevisiae, P. stipitis ATCC 58785 and the selected fusants with other references.

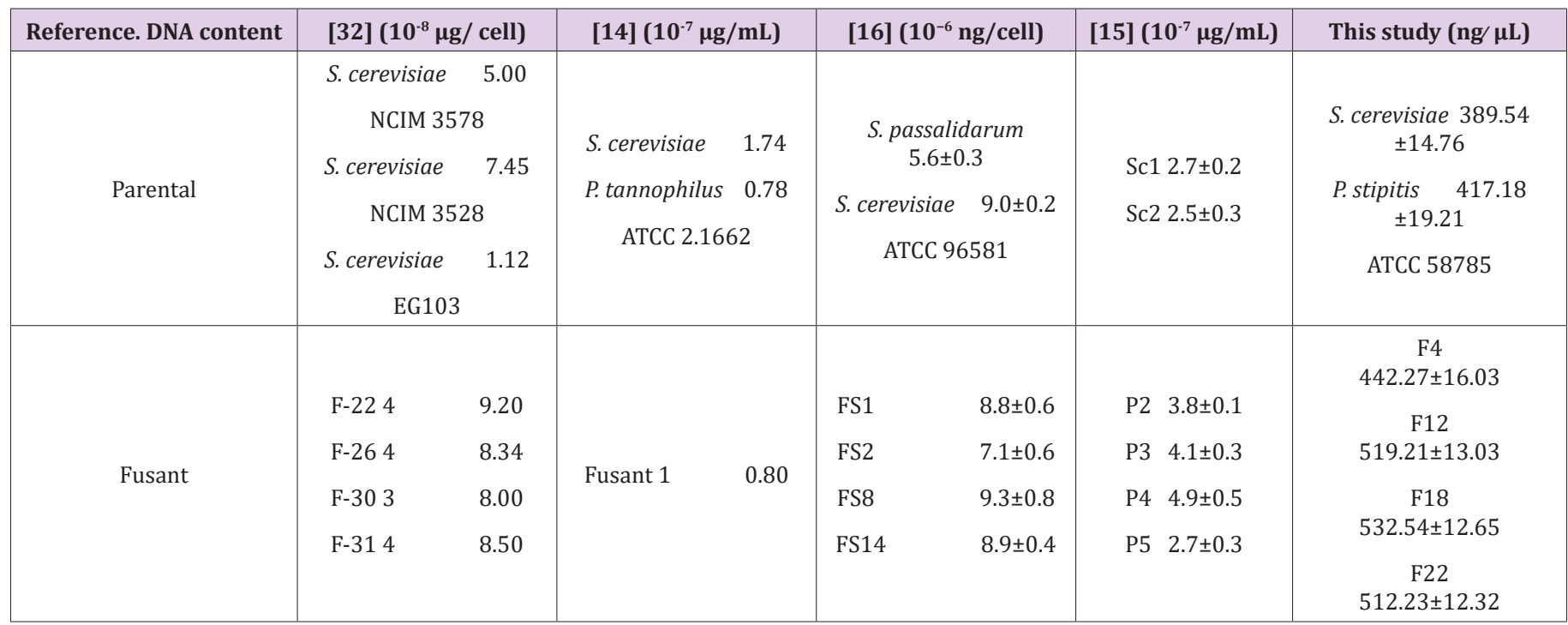




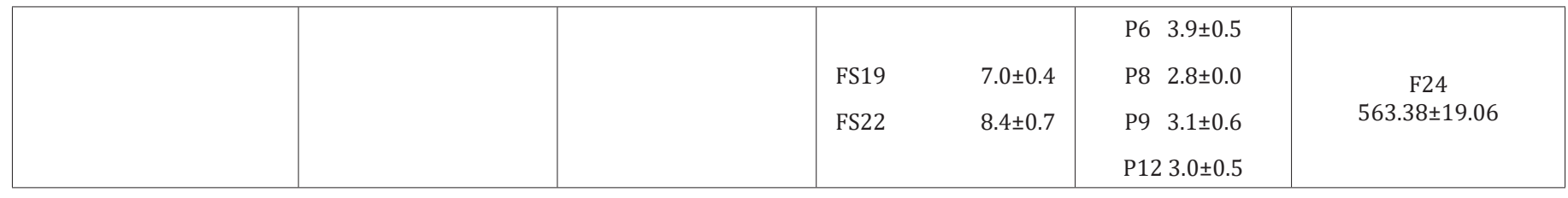

These findings are consistent with the findings reported by [14], who similarly reported that DNA content values determined in fusant $\mathrm{F} 1$ was $0.8 \times 10-7 \mu \mathrm{g} / \mathrm{mL}$ which was compared to the value expected by the addition of the parental values $\mathrm{S}$. cerevisiae $1.74 \times 10-7 \mu \mathrm{g} / \mathrm{mL}$ and P. tannophilus ATCC 2.1662 as $0.78 \times 10-7$ $\mu \mathrm{g} / \mathrm{mL}$ DNA content. In another earlier study, [15] reported that DNA content values detected in fusants whose parent had 2.7 to $4.9 \times 10-7 \mu \mathrm{g} / \mathrm{mL}$ DNA content were significantly lower compared to the value expected by the addition of the parental values $5.2 \times 10$ $7 \mu \mathrm{g} / \mathrm{mL}$, just as similarly observed in this study. However, some fusants were found to have DNA content values that were not considerably different from those exhibited by the parental strains, indicating a significant loss of genetic materials. In a related study, the results of six putative hybrid strains and the parental strains of S. passalidarum M7 and S. cerevisiae ATCC 96581 showed that all putative hybrids contained different quantities of DNA, but all values were higher than that in the parental strain S. passalidarum M7 as similarly reported in this study [16].

\section{Random Amplified Polymorphic DNA}

RAPD profile has been frequently used to identify variations in DNA level among yeast strains $[17,18]$. In this study, molecular characterization of the parental stock of $S$. cerevisiae and P. stipitis ATCC 58785 and fusants F4, F12, F18, F22 and F24 using RAPD profiling was carried out to know the genetic similarities of the fusant with parental strains as depicted in Figure 2. The profile of fusants represented in L3 to L7, showed diverse pattern of bands compared with parental strains. These strains were observed to share some of the polymorphic bands with $S$. Cerevisiae and some with P. Stipitis ATCC 58785, even though P. Stipitis ATCC 58785 has closer similarity compared to $S$. Cerevisiae. F4 was observed to possess band $1200 \mathrm{bp}$ and $\approx 600 \mathrm{bp}$ originated from $S$. Cerevisiae and band $\approx 800$ bp originated from P. Stipitis ATCC 58785, near while F12 observed to possess band $1200 \mathrm{bp}$ originated from $S$. Cerevisiae and band $\approx 1000 \mathrm{bp}$ originated from P. Stipitis ATCC 58785 . However F18 observed to possess band 1600 bp originated from $S$. Cerevisiae, band $\approx 1200 \mathrm{bp}$ and band $\approx 500$ bp originated from P. Stipitis ATCC 58785, F22 observed to possess band $1000 \mathrm{bp}$, band 900 bp and band 700 bp originated from S. Cerevisiae, band $\approx 1000$ bp and band $\approx 800$ bp originated from P. Stipitis ATCC 58785, F24 observed to possess band $1000 \mathrm{bp}$, band $900 \mathrm{bp}$ and band 700 bp originated from $S$. Cerevisiae, band $\approx 1200 \mathrm{bp}$ and band $\approx 700 \mathrm{bp}$ originated from P. Stipitis ATCC 58785. These findings corroborate with the report of Guillamon and Barrio (2017), who observed and reported RAPD produced pattern of amplified products of different molecular weights that are characteristic of either the species or the different strains or isolates within the same species. The RAPD has also been reported to have the advantages of simplicity, efficiency, relative ease of execution, and no requirement of any previous sequence information [8,19-21]. Thus, the RAPD profile justifies the fusant nature of the fusants strain.

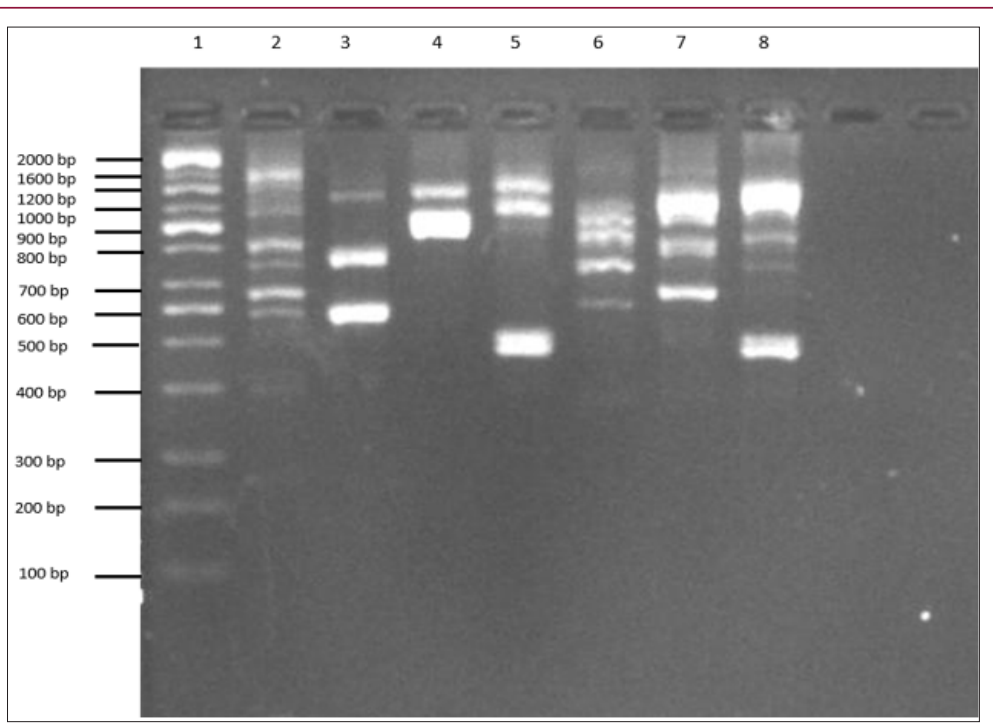

Figure 2: RAPD profile of parental S. cerevisiae, P. stipitis ATCC 58785 and fusants. Lane 1:100 bp DNA ladder, Lane 2: S. cerevisiae, Lane 3: F4, Lane 4: F12, Lane 5: F18, Lane 6: F22, Lane 7: F24 and Lane 8: P. stipitis ATCC 58785. The product was electrophoresis on $1.5 \%$ agarose with 1 X TBE buffer at 70 voltage for $1.5 \mathrm{~h}$ and visualized under U.V light.

\section{Sequencing Analysis}

The DNA sequencing, which includes two non-coding regions designated as the internal transcribed spacers (ITS1 and ITS2) and the 5.8S gene was performed for further confirmation of the fusant nature of fusants F12, F18, F22 and F24. Fusant F4 was eliminated due to low performance in bioethanol yield. The ITS1 primer and 
a primer ITS4 were used to amplify the ITS1 and ITS2 and 5.8S gene. PCR product the band size $600 \mathrm{bp}$ was electrophoresis on agarose gel (Figure 3). The nuclear internal transcribed spacer (ITS) regions have been employed as molecular markers because of their relative variability and ease of PCR amplification [22]. The ITS array consists of the entire ITS1, 5.8S and ITS2 regions of the nuclear rDNA cistron. It is a multigene family with the potential for variation among tandem repeats. Polymorphisms are not uniformly distributed across the ITS array. The 5.8S gene sequence is highly conserved but the ITS1 and ITS2 sequences are more variable and are highly polymorphic depending on the fungal species $[7,23]$.

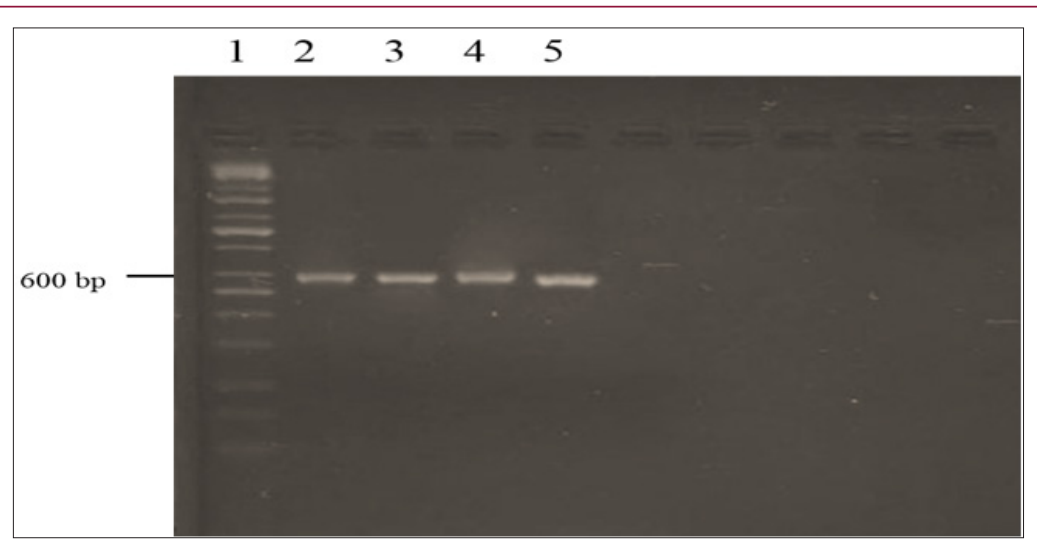

Figure 3: PCR product the band size 600 bp of ITS gene for fusant strains. Lane 1:100 bp DNA ladder, Lane 2: F12, Lane 3: F18, Lane 4: F22 and Lane 5: F 24. The product was electrophoresis on 1.5\% agarose with 1X TBE buffer at 70 voltage for $1.5 \mathrm{~h}$ and visualized under U.V light.

It being widely used for phylogenetic inference and in systematics, the ITS region is the formal fungal barcode and is the primary choice for molecular identification of fungi from a number of sources [24]. ITS-PCR profile of two parent strains, fusants and relative strains compare with National Centre Biotechnology Information (NCBI). According to genetic similarity and intraspecies differentiation, two parent strains and fusants were grouped into two different clusters. S. Cerevisiae which correspond to $88 \%$ sequence similarity whereas approximately $97 \%$ similarity was observed with P. Stipitis ATCC 58785 (Figure 4). The parent strain P. stipitis ATCC 58785 and fusants (F12, F18, F22 and F24) were grouped in the first cluster and the other parent $S$. Cerevisiae were grouped in the second cluster. Fusant F12 was found to be closely related to Scheffersomyces segobiensis LC12358, Fusant F18 was found to be closely related to Scheffersomyces illinoinensis NR111865, Fusant F22 was found to be closely related to Meyerozyma guilliermondii (Pichia guilliermondii) EF643576 and Fusant F24 was found to be closely related to Scheffersomyces shehatae LC120361.

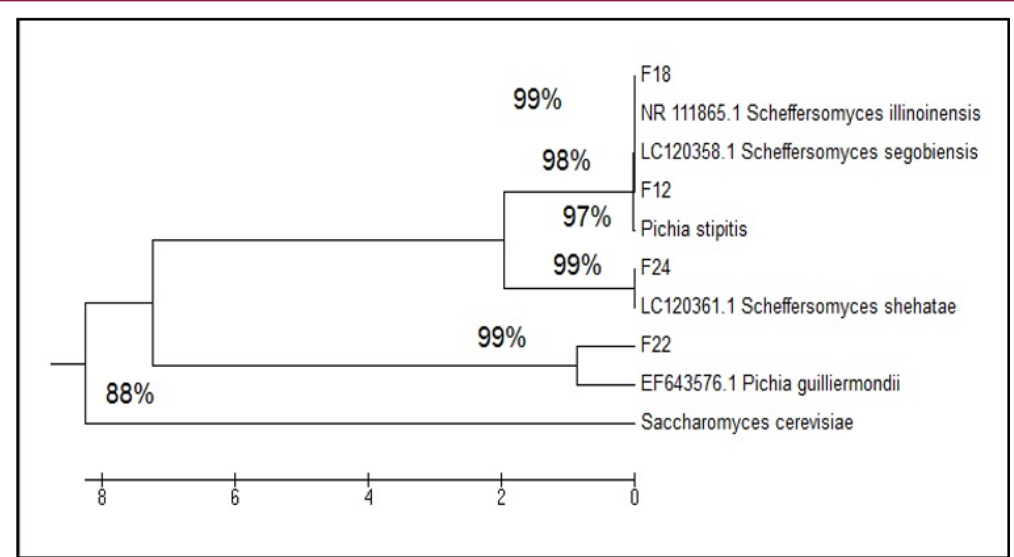

Figure 4: ITS-PCR profile of parental S. cerevisiae, P. stipitis ATCC 58785, fusants and relative strains compare with NCBI.

The results are in accordance with the findings of [25], as reported that the fusant usually resembles any one of the parent in its properties and supported the fact that the fusants consist of the entire genome of the parent with which they possessed most of the characteristics, together with a chromosome from the other parent. The sequence of the ITS1, ITS2 and the 5.8S gene of each fusants was submitted to Genbank with the NCBI ACESSION NO (Table 7). In general, the obtained new combination of DNA fragment patterns and the presence of new DNA fragment or the absence of existing parental DNA fragments in the fusant strains compared to their parents could be considered as indicator of nuclear fusion of the two parental nuclei in the fused protoplasts. The sequencing of a region of the rDNA gene unit, which includes two non-coding regions designated as the internal transcribed spacers (ITS1 and ITS2) and the 5.8S gene of fusants F12, F18, F22 and F24 as shown in (Appendix 1-4) receptively. Molecular study using sodium dodecylsulphate polyacrylamide gel electrophoresis (SDS-PAGE) was employed to identify the genetic inter-relationship between fusants and their parents [26-28]. 
Table 7: Fusants with the Genbank NCBI ACCESSION NO.

\begin{tabular}{|c|c|}
\hline Fusants & NCBI ACCESSION NO. \\
\hline $\begin{array}{c}\text { Scheffersomyces segobiensis strain } \\
\text { F12 }\end{array}$ & MH429780.1 \\
\hline $\begin{array}{c}\text { Scheffersomyces illinoinensis strain } \\
\text { F18 }\end{array}$ & MH429781.1 \\
\hline $\begin{array}{c}\text { Meyerozyma guilliermondii strain } \\
\text { F22 (Pichia guilliermondii) }\end{array}$ & MH429782.1 \\
\hline $\begin{array}{c}\text { Scheffersomyces shehatae strain } \\
\text { F24 }\end{array}$ & MH429783.1 \\
\hline
\end{tabular}

\section{Determination of Protein Concentration}

The protein contents of fusant F24 was found $504 \mu \mathrm{g} / \mathrm{mL}$. The protein contents of fusant F22 was found to have increased to $654 \mu \mathrm{g} / \mathrm{mL}$ while those of fusant F4 and F12 were found to below which reached $368 \mu \mathrm{g} / \mathrm{mL}$ and $342 \mu \mathrm{g} / \mathrm{mL}$ respectively. The protein contents of fusant F18 was found to be comparable to the parental strain for P. stipitis ATCC 58785 as $485 \mu \mathrm{g} / \mathrm{mL}$ (Table 8), These results were in agreement with Hassan, 2014 who tested 17 fusants obtained from protoplast fusion between T. harzianum and T. viride and found that the protein content of fusant $16(322.3 \mu \mathrm{g} / \mathrm{mL})$ was significantly higher compared to those of fusant 3 and fusant $8(184.3 \mu \mathrm{g} / \mathrm{mL}$ and $191.7 \mu \mathrm{g} / \mathrm{mL})$ which were significantly low. The protein contents of fusant F22 and F24 $(654 \mu \mathrm{g} / \mathrm{mL}$ and 504 $\mu \mathrm{g} / \mathrm{mL}$ ) were higher compared to the parental strain for P. Stipitis ATCC 58785 as $489 \mu \mathrm{g} / \mathrm{mL}$. As similarly observed in this study, the protein contents of fusant 16 in the said study (Hassan, 2014) was significantly higher compared to those of the parental strains $(223.7 \mu \mathrm{g} / \mathrm{mL}$ and $229.3 \mu \mathrm{g} / \mathrm{mL}$ ) for Trichoderma parental isolates. These results are indications that partial or incomplete genetic recombination might be taken place during protoplast fusion. [27] observed higher protein content in fusant compared to the parental strain in intrageneric protoplast fusion between Aspergillus oryzae and Trichoderma harzianum, protein content of the fusant was 60 $\mu \mathrm{g} / \mathrm{mL}$ while those of the parental strain were $27 \mu \mathrm{g} / \mathrm{mL}$ and 15 $\mu \mathrm{g} / \mathrm{mL}$ for A. oryzae and T. harzianum respectively. [29] carried out protoplast fusion between T. harzianum and T. viride and found that fusant HF9 exhibited 1.5fold increases in total protein content compared to the protein content of parental strains.
Table 8: Whole cell protein concentration of parent and fusants strain.

\begin{tabular}{|c|c|}
\hline Strain & Protein concentration $(\boldsymbol{\mu g} / \mathbf{m L})$ \\
\hline S. cerevisiae & 737 \\
\hline P. stipitis ATCC 58785 & 489 \\
\hline F4 & 368 \\
\hline F12 & 342 \\
\hline F18 & 485 \\
\hline F22 & 654 \\
\hline F24 & 504 \\
\hline
\end{tabular}

\section{SDS-PAGE Analysis}

SDS-PAGE was utilized to analyse the polypeptide profile of $S$. Cerevisiae, P. Stipitis ATCC 58785 and the fusants culture proteins. The polypeptide profile was seen with reference to a protein ladder (GangNam-STAIN ${ }^{\mathrm{TM}}$ Prestained), with 12 bands between 10 to 245 $\mathrm{kDa}$. SDS-AGE protein analysis of the five selected fusants and their parental strains confirmed that all fusant strains acquired and expressed many specific protein bands from the parental strains as similarly reported in an earlier study [26]. Protein bands with high molecular masses of $100 \mathrm{kDa}$, which existed in S. Cerevisiae parental strain and not in P. Stipitis ATCC 58785 parental strain was expressed in the fusants F22 and F24. Two other protein bands with molecular masses of 48 and $20 \mathrm{kDa}$, which existed in P. Stipitis ATCC 58785 parental strain and not in S. cerevisiae parental strain, were also expressed in fusants, protein bands with molecular masses of $48 \mathrm{kDa}$ existed in fusant F18 and F22 while protein bands of $20 \mathrm{kDa}$ existed in F18, F22 and F24. The similar bands from parents that were expressed in the fusants are indications of protoplast fusion between two yeasts S. Cerevisiae and P. Stipitis ATCC 58785 (Figure 5). These findings of acquisition of different proteins by the fusant from the parental strains as observed in this study agree with those reported by [26], who found that 17 selected fusants obtained in their study and their parental strains confirmed that all fusant strains acquired and expressed many specific protein bands from the parental strains [26]. [30] used SDS-PAGE analysis for screening of the fused cultures from protoplast fusion of the polypeptide profile yeast cultures S. Cerevisiae and K. Marxianus for enhancing bioethanol production from cheese industry waste [31-34].

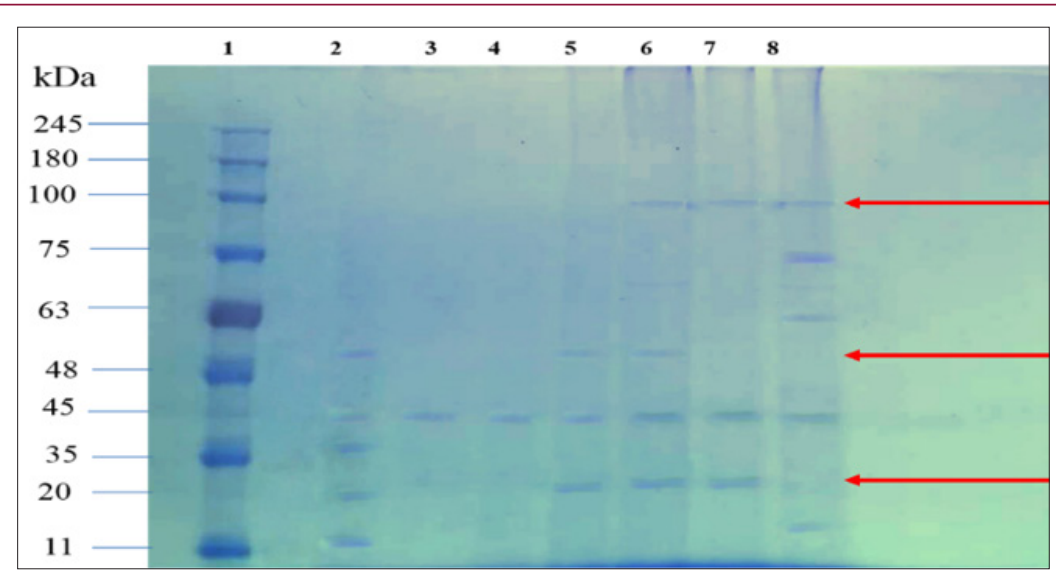

Figure 5: The polypeptide profile of the parental S. cerevisiae, P. stipitis ATCC 58785 and fusants. Lane 1: protein marker, Lane 2: P. stipitis ATCC 58785, Lane 3: F4, Lane 4: F12, Lane 5: F18, Lane 6: F22, Lane 7: F24 and Lane 8: S. cerevisiae.

Cite this article: Fawzia Jassim S, Noor Azlina I, Mohammed A, Anis Shobirin B M H. Molecular Genetic Characterization of Fusants from Protoplast Fusion of S. Cerevisiae and P. Stipitis ATCC 58785. Biomed J Sci \& Tech Res 12(4)-2019. BJSTR. MS.ID.002272. DOI: 10.26717/ 


\section{References}

1. Radhika K, Ravinder R, Ravindra P (2011) Bioconversion of pentose sugars into ethanol: A review and future directions. Biotechnology and Molecular Biology Reviews 6(1): 8-20.

2. Kahar P, Tanaka S (2014) A xylose-fermenting yeast hybridized by intergeneric fusion between Saccharomyces cerevisiae and Candida intermedia mutants for ethanol production. Sustainable Chemical Processes 2(1): 1-12.

3. Ge J, Zhao J, Zhang L, Zhang M, Ping W (2014) Construction and analysis of high-ethanol-producing fusants with co-fermentation ability through protoplast fusion and double labeling technology. Plos one 9(9): e108311.

4. Van den Berg MA, Maruthachalam K (2015) Genetic Transformation Systems in Fungi Springer 2: 125-234.

5. Sambrook J, Fritsch EF, Maniatis T (1989) Molecular cloning: a laboratory manual (Ed. 2). Cold spring harbor laboratory press.

6. Omear HA, Al Assie AH, Dhahi SJ (2011) Application of the randomly amplified polymorphic DNA (RAPD) Markers to analyze the genetic variability in species of the fungus Alternaria. Rafidain Journal of Science 22(1): 1-16.

7. Rampersad SN (2014) ITS1 5.8S and ITS2 secondary structure modelling for intra-specific differentiation among species of the Colletotrichum gloeosporioides sensu lato species complex. SpringerPlus 3(1): 684694.

8. Lakhani HN, Vakharia DN, Hassan MM, Eissa RA (2016) Fingerprinting and molecular comparison among two parental strains of Trichoderma spp. and their corresponding fusants produced by protoplast fusion. Biotechnology and Biotechnological Equipment 30(6): 1065-1074.

9. White TJ, Bruns T, Lee SJ WT, Taylor JL (1990) Amplification and direct sequencing of fungal ribosomal RNA genes for phylogenetics. PCR Protocols: A Guide to Methods and Applications 18(1): 315-322.

10. Bałdyga J, Jasinska M, Dziegielewska M, Zochowska M (2012) Disruption of yeast cells with ultrasound. In Proceedings of 14th European Conference on Mixing p. 25-30.

11. Han IN, Hong Van LH, Duc TV, Dao DT (2015) Optimizing yeast cell Saccharomyces cerevisiae disruption by sonication treatment. International Journal of Engineering and Technology Research 3(4) 281-286.

12. Bradford MM (1976) A rapid and sensitive method for the quantitation of microgram quantities of protein utilizing the principle of protein-dye binding. Analytical Biochemistry 72(1-2): 248-254.

13. Hames BD (1981) Introduction to polyacrylamide gel electrophoresis Gel electrophoresis of proteins. Oxford: IRL Press, p. 1-91.

14. Yan F, Bai F, Tian S, Zhang J, Zhang Z, et al. (2009) Strain construction for ethanol production from dilute-acid lignocellulosic hydrolysate. Applied Biochemistry and Biotechnology 157(3): 473-482.

15. Perez L, Lopes CA, Barrio E, Querol A (2012) Evaluation of different genetic procedures for the generation of artificial hybrids in Saccharomyces genus for winemaking. International Journal of Food Microbiology 156(2): 102-111.

16. Hou X, Yao S (2012) Improved inhibitor tolerance in xylose-fermenting yeast Spathaspora passalidarum by mutagenesis and protoplast fusion. Applied Microbiology and Biotechnology 93(6): 2591-2601.

17. Zhang W, Geng A (2012) Improved ethanol production by a xylose -fermenting yeast strain constructed through a modified genome shuffling method. Biotechnology for Biofuels 5: 46-58.
18. Guo X, Wang R, Chen Y, Xiao D (2012) Intergeneric yeast fusants with efficient ethanol production from cheese whey powder solution: construction of a Kluyveromyces marxianus and Saccharomyces cerevisiae AY-5 hybrid. Engineering in Life Sciences 12(6): 656-661.

19. Andrighetto C, Psomas E, Tzanetakis N, Suzzi G, Lombardi A (2000) Randomly amplified polymorphic DNA (RAPD) PCR for the identification of yeasts isolated from dairy products. Letters in Applied Microbiology 30(1): 5-9.

20. Pfliegler WP, Horvath E, Kallai Z, Sipiczki M (2014) Diversity of Candida zemplinina isolates inferred from RAPD, micro/minisatellite and physiological analysis. Microbiological Research 169(5-6): 402-410.

21. Van der Westhuizen TJ, Augustyn OPH, Pretorius IS (2017) The value of long-chain fatty acid analysis, randomly amplified polymorphic DNA and electrophoretic karyotyping for the characterization of wine yeast strains. South African Journal of Enology and Viticulture 20(1): 3-10.

22. Nilsson RH, Tedersoo L, Abarenkov K, Ryberg M, Kristiansson E, et al. (2012) Five simple guidelines for establishing basic authenticity and reliability of newly generated fungal ITS sequences. Myco Keys 4: 37-63.

23. Seifert KA (2009) Progress towards DNA barcoding of fungi. Molecular Ecology Resources 9: 83-89.

24. Schoch CL, Seifert KA, Huhndorf S, Robert V, Spouge JL, et al. (2012) Nuclear ribosomal internal transcribed spacer (ITS) region as a universal DNA barcode marker for Fungi. Proceedings of the National Academy of Sciences 109(16): 6241-6246.

25. Yoon GS, Lee T, Ryu YW, Kim C, Seo J (1996) Characterization of alcohol fermentation and segregation of protoplast fusant of Saccharomyces cerevisiae and Pichia stipitis. Journal of Microbiology and Biotechnology 6(4): 286-291.

26. El Kawokgy TM, Hussein HA, Aly NA, Mohamed SA (2014) Highly toxic and broad-spectrum insecticidal local Bacillus strains engineered using protoplast fusion. Canadian Journal of Microbiology 61(1): 38-47.

27. Patil NS, Patil SM, Govindwar SP, Jadhav JP (2015) Molecular characterization of intergeneric hybrid between Aspergillus oryzae and Trichoderma harzianum by protoplast fusion. Journal of Applied Microbiology 118(2): 390-398.

28. Aggag S, Shoman R, Moussa M, Yacout M (2017) Organophosphorus pesticides biodegradation by three bacterial genera and their protoplast fusants. Journal of Applied Biological Sciences 11(3): 29-32.

29. Balasubramanian N, Priya VT, Gomathinayagam S, Lalithakumari D (2012) Fusant Trichoderma HF9 with enhanced extracellular chitinase and protein content. Applied Biochemistry and Microbiology 48(4): 409-415.

30. Krishnamoorthy N, Vijila K, Kumutha K (2010) Intergeneric protoplast fusion of yeast for high ethanol production from cheese industry waste Whey. Journal of Yeast and Fungal Research 1(5): 81-87.

31. Guillamon JM, Barrio E (2017) Genetic Polymorphism in Wine Yeasts: Mechanisms and Methods for Its Detection. Frontiers in Microbiology 8: 806 .

32. Javadekar VS, SivaRamn NH, Gokhale DV (1995) Industrial yeast strain improvement: construction of a highly flocculent yeast with a killer character by protoplast fusion. Journal of Industrial Microbiology and Biotechnology 15(2): 94-102.

33. Laemmli UK (1970) Cleavage of structural proteins during the assembly of the head of bacteriophage T4. Nature 227: 680-685.

34. Spent NF, Yeast B (2003) Selected biotechnological features of hybrids of Saccharomyces cerevisiae and Yamadazyma stipitis. Biotechnology 6(1): 1-8. 


\section{ISSN: 2574-1241}

DOI: $10.26717 / B J S T R .2019 .12 .002272$

Noor Azlina Ibrahim. Biomed J Sci \& Tech Res

(c) (1) This work is licensed under Creative

Submission Link: https://biomedres.us/submit-manuscript.php

$\begin{array}{ll}\text { BIOMEDICAL } & \text { Assets of Publishing with us } \\ \text { RESEARCHES } & \text { - Global archiving of articles } \\ \text { - Immediate, unrestricted online access }\end{array}$

